\title{
Bone Desmoplastic Fibroma
}

National Cancer Institute

\section{Source}

National Cancer Institute. Bone Desmoplastic Fibroma. NCI Thesaurus. Code C3740.

A rare, benign, locally aggressive, osteolytic neoplasm. It is characterized by the presence of a rich collagenous stroma and spindle cells with minimal cellular atypia. 